\title{
THE TRADE-OFF BETWEEN UNEMPLOYMENT AND WAGE INEQUALITY REVISITED
}

\section{Alena Bičáková}

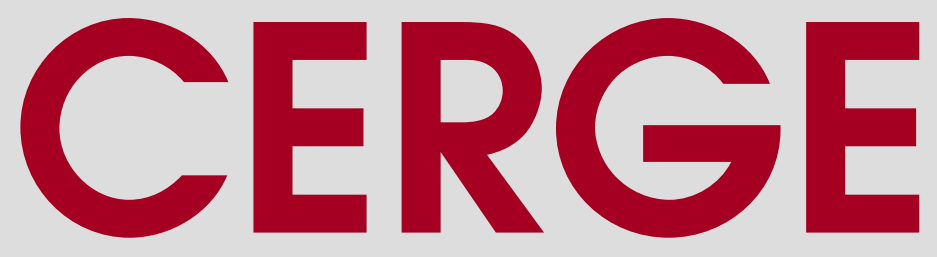

Charles University

Centerfor Economic Research and Graduate Education

Academy of Sciences of the Czech Republic

Economic Institute 


\title{
Working Paper Series $\quad 502$ (ISSN 1211-3298)
}

\section{The Trade-off Between Unemployment and Wage Inequality Revisited}

\author{
Alena Bičáková
}

CERGE-EI

Prague, January 2014 
ISBN 978-80-7343-306-2 (Univerzita Karlova. Centrum pro ekonomický výzkum a doktorské studium)

ISBN 978-80-7344-299-6 (Akademie věd České republiky. Národohospodářský ústav) 


\title{
The Trade-off Between Unemployment and Wage Inequality Revisited*
}

\author{
Alena Bičáková
}

\author{
CERGE-EI ${ }^{\dagger}$
}

\begin{abstract}
The Krugman hypothesis attributes high wage inequality in the US and high unemployment in continental Europe in the 1980s to the same negative change in the demand for the low skilled under different degrees of wage rigidity. This paper revisits the hypothesis in order to explain the labor market developments in France, the UK, and the US in the 1990s. We estimate a labor supply and labor demand model with heterogenous types of labor to analyze the effects of market forces and wage rigidity on changes in skill-group labor market outcomes. The results provide evidence in favor of the Krugman hypothesis when France is compared to the US and the UK. We also find support for an extended version of the Krugman hypothesis, which suggests that, when labor supply is sensitive to wages, there is a trade-off between unemployment on one hand, and wage inequality and inactivity on the other.
\end{abstract}

\begin{abstract}
Abstrakt
Pokud jde o vysokou mzdovou nerovnost v USA a vysokou nezaměstnanost v zemích evropského kontinentu v osmdesátých letech dvacátého století, Krugmanova hypotéza připisuje oba jevy poklesu poptávky po pracujících s nízkou kvalifikací, jehož důsledky se liší podle různého stupně mzdové rigidity. Předkládaná studie zkoumá, zda tato hypotéza je schopna vysvětlit také vývoj na trhu práce ve Francii, Velké Británii a USA také v následující dekádě, v letech devadesátých. Odhadujeme model nabídky práce a poptávky po práci s heterogenními typy pracujících, jehož pomocí analyzujeme vliv tržních sil a mzdové rigidity na pozorované změny výstupů na trhu práce skupin pracujících s odlišnou kvalifikací. Naše výsledky ukazují, že pomocí Krugmanovy hypotézy lze vysvětlit rozdílný vývoj na trhu práce ve Francii ve srovnání s USA a Velkou Británií. Nacházíme také empirickou relevanci rozšířené verze Krugmanovy hypotézy, která říká, že pokud je nabídka práce citlivá na mzdy, existuje substituční vztah mezi nezaměstnaností na jedné straně a mzdovou nerovností a neparticipací na trhu práce na straně druhé.
\end{abstract}

Keywords: Krugman hypothesis; Wage Rigidity; Unemployment; Inactivity;

JEL classification: J21, J23, J31

*I am grateful to Robert Moffitt for many helpful comments, as well as for letting me use his pre-transformed version of the Current Population Survey data for the US. This paper has also benefited from discussions with Richard Spady, Andrea Ichino, Giuseppe Bertola, and from comments made by participants at the seminars at EUI (Florence), IZA (Bonn) and CERGE-EI (Prague). The data for France and the UK were kindly provided by the national statistical offices: Enquête Emploi from LASMAS-IdL and Labor Force Survey from the UK Data Archive.

${ }^{\dagger}$ CERGE-EI is a joint workplace of Charles University and the Economics Institute of the Academy of Sciences of the Czech Republic, Politickych veznu 7, 11121 Prague, Czech Republic. E-mail: alena.bicakova@cerge-ei.cz 


\section{Introduction}

The Krugman hypothesis offered a joint explanation for an increase in wage inequality in the US and the rise in unemployment in countries of Continental Europe over the 1980s, suggesting that both phenomena were driven by the same skill-biased shift in the demand but under different degree of wage rigidity (Krugman 1994 and Blank 1997). The hypothesis implies that policy-makers whose goal is to mitigate the consequences of a decline in the demand for the low skilled face a trade-off between unemployment and wage inequality, driven by labor market institutions that affect wage-setting mechanisms. Given the persistence of the negative effects of the recent Great Recession, the hypothesis remains highly relevant for policies aimed at reducing unemployment even today.

Despite the importance of the Krugman hypothesis, few papers have directly tested its predictions and the evidence is mixed. Card, Kramarz, and Lemieux (1999) analyze a long-term change in the skill-specific wages and employment over the 1980s for France, Canada and the US, and reject the Krugman hypothesis when France and Canada are compared to the US. Puhani (2008), on the other hand, focuses on the relative wages and employment rates in the UK, the US, and Germany, and finds evidence in favor of the Krugman hypothesis for the 1980s and 1990s when Germany is compared to the US. Over a similar period, Fitzenberger and Garloff (2008) analyze unemployment and wage inequality in West Germany and find no support for the Krugman hypothesis when looking at the relationship between within-cell wage dispersion and unemployment by cells. Their findings, however, carry no implications for the validity of the Krugman hypothesis for between-group differences in relative wages and unemployment, which are the focus of Card et al. (1999) and Puhani (2008) as well as our study (Fitzenberger and Garloff 2008).

The underlying idea of the Krugman hypothesis has been also invoked by a

Academy of Sciences of the Czech Republic, Politickych veznu 7, 11121 Prague, Czech Republic. E-mail: alena.bicakova@cerge-ei.cz 
wider range of research. Any paper that relates labor market institutions that affect wage flexibility to relative employment or unemployment of the low skilled provides evidence, even if indirect, for or against the Krugman hypothesis. ${ }^{1}$ Using a panel of 17 OECD countries over the 1960-96 period and allowing for country fixed effects, Bertola, Blau, and Kahn (2007) show that wage-setting institutions, which increase wage rigidity, cause larger disemployment effects for the young and old, relative to prime age individuals, and increase female unemployment relative to that of men. Using a panel of 15 OECD countries from 1985 to 1994, Kahn (2000) concludes that greater union coverage and membership increase relative wages and lower relative employment for less-skilled men. The effect on wages is similar for lowskilled women, but the evidence of negative employment effects are weaker. Oesch (2010), on the other hand, analyzes determinants of unemployment among the low skilled in 21 OECD countries over 1990s and finds no evidence that minimum wage and wage inequality decrease low-skilled employment. ${ }^{2}$

Clearly, research directly testing the Krugman hypothesis is scarce and its findings contradictory. This paper revisits the empirical relevance of the Krugman hypothesis by asking whether it can explain the diverse labor market developments in the US and the UK, two countries with flexible labor markets, compared to France, a country with relatively high wage rigidity, over the 1990s. Specifically, the 1990s was a period of continued rise of unemployment in France and of continued increase in wage inequality, also accompanied by a new trend of rising male inactivity, in the US and the UK. ${ }^{3}$ We contribute to the limited research that directly tests the Krugman hypothesis not merely by providing further evidence for another set of countries over a new period but also, primarily, by employing a novel estimation framework that we believe has several advantages over previous work.

\footnotetext{
${ }^{1}$ The test is indirect, as it is not clear whether the channel behind this relationship goes indeed through wage rigidity, e.g. the compression of wage distribution.

${ }^{2}$ As the analysis in Oesch (2010) does not include country fixed-effects, the results may be biased by country-specific unobserved heterogeneity correlated with the analyzed determinants of low-skilled unemployment, and may not be comparable with the other studies.

${ }^{3}$ By inactivity, we mean the state of voluntary non-employment, sometimes also called out of labor force or labor force non-participation.
} 
We follow the direction of Card et al. (1999), our closest antecedent, and Puhani (2008), and formulate the Krugman hypothesis in terms of a simple model of labor supply and labor demand with heterogeneous labor. In contrast with the two previous studies, however, we estimate the model directly and base our test of the Krugman hypothesis on the estimates of its underlying parameters, rather than on correlations between relative net demand shocks and wage rigidities, as in Puhani (2008), or reduced form coefficients relating demand and supply shocks to relative wages and employment, as in Card et al. (1999). We note that the results of the tests based on the correlations or reduced form estimation of the sensitivity of wages and employment to shocks may be also driven by cross-country differences in other underlying parameters of the model, such as elasticity of substitution between different skill-groups. The estimation of all the relevant parameters of the labor supply and labor demand model allow us to account for these differences.

Both Card et al. (1999) and Puhani (2008) focus on long-term changes (over a decade) in relative wages and employment, as a consequence of the skill-biased technological progress over the 1980s (also the 1990s for the latter study), using cross-sectional data. Instead, we consider year-to-year changes in wage and labor force status skill differentials using group-level panel data, which, we believe better fit both the pace of technological progress over 1990s and, in particular, the frequency of wage adjustments under wage rigidity. Using annual data to estimate our model, we allow for year-to-year wage adjustments, which are consistent with the empirical evidence from France that a typical duration between two wage decisions by wage agreements is 12 months (Avouyi-Dovi, Fougere, and Gautier 2013). We construct an annual pseudo-panel of different skill-groups for the period between 1990 and 2002 from the labor force surveys of the three countries: Enquête Emploi for France, Labor Force Survey for the UK, and the March CPS for the US.

Finally, we propose an extended version of the Krugman hypothesis, which focuses not only on wage inequality and unemployment but also on labor supply. When labor force participation is sensitive to wages, then rising wage inequality 
is likely to be accompanied by an increase in the inactivity rate, suggesting that depending on the institutions that affect wage rigidity there is a trade-off between unemployment on one hand, and wage inequality and inactivity on the other. In the model, we relax the assumption of perfectly inelastic labor supply maintained by the previous studies and estimate the wage elasticity of labor supply in order to test the relevance of the extended version of the Krugman hypothesis.

Contrary to Card et al. (1999), we do find support for the Krugman hypothesis when comparing France to the US and the UK over the 1990s, with the UK having the more flexible wages than the US. The estimated parameter of the degree of wage flexibility, which captures the part of the change in the underlying marketclearing wage that is translated into the observed wage, is 0.84 in the US and the UK, compared to 0.80 in France in our baseline model. Focusing specifically on the bottom of the wage distribution, wage flexibility is estimated to be 0.96 in the UK, 0.83 in the US, but only 0.74 in France, which is in line with the relative importance of statutory minimum wages in the two countries and the fact that the minimum wage was established in the UK only towards the end of the analyzed period, in 1999. The positive and significant values of the wage elasticity of labor force participation for all three countries, in particular among women, provide support for the extended Krugman hypothesis. Wage elastic labor supply of men in the UK also suggests that the documented rise in male inactivity there is likely to be a consequence of the continuing deterioration of the relative wages of the low skilled.

This paper has the following structure: The introduction is followed by a section that defines the Krugman hypothesis and its extension and discusses previous research. The third section provides an overview of the institutional background and macroeconomic development of the three analyzed countries. The fourth section sets up the model, while the fifth section explains how it is estimated and describes the data. This is followed by the the sixth section that covers all the results, including the baseline estimates, and three robustness checks and extensions. The seventh section concludes. The Appendix contains data description, details of the model 
and the estimation details.

\section{The Krugman Hypothesis and Previous Research}

When wages are rigid, skill-biased shift in the demand will result in a rise in unemployment among the low skilled, leaving relative wages intact. When wages are flexible and the labor supply is perfectly wage inelastic, ${ }^{4}$ the adverse demand shift will lead to a decline in relative wages of the low skilled, while their relative employment will remain at its initial level. The standard Krugman hypothesis states that in the face of the skill-biased demand shock, there is a trade-off between wage inequality and unemployment, depending on wage flexibility.

However, when the labor supply is not perfectly inelastic, the standard Krugman hypothesis is incomplete. This is illustrated by Figure 1, which compares the effect of an adverse demand shift on the relative earnings and employment of the low skilled (relative to the high skilled) workers in a country where wages are rigid, such as France, and in a country where wages are flexible, such as the US, in a simple static model of labor supply and labor demand. If labor supply is sensitive to wages, deterioration of the relative wages of the low skilled in countries where wages are flexible will reduce the incentives of the low skilled to work, which will result in a partial decline in their employment along the labor supply curve (and a rise in their inactivity). Note that the more elastic the labor supply, the smaller the relative wage deterioration in a country with flexible wages, and the greater the decline in the relative employment of the low skilled in the two types of countries. We conclude that under a reasonable assumption of non-zero wage elasticity of labor supply, in consequence of a skill-biased shift in labor demand, there is a trade-off depending on labor market institutions affecting wage flexibility - between a rise in unemployment on the one hand and a rise in wage inequality and inactivity on the other. This is what we call the extended version of the Krugman hypothesis.

\footnotetext{
${ }^{4}$ In what follows, labor supply is defined as labor force participation and the two terms are used interchangeably.
} 
Figure 1: The Krugman hypothesis

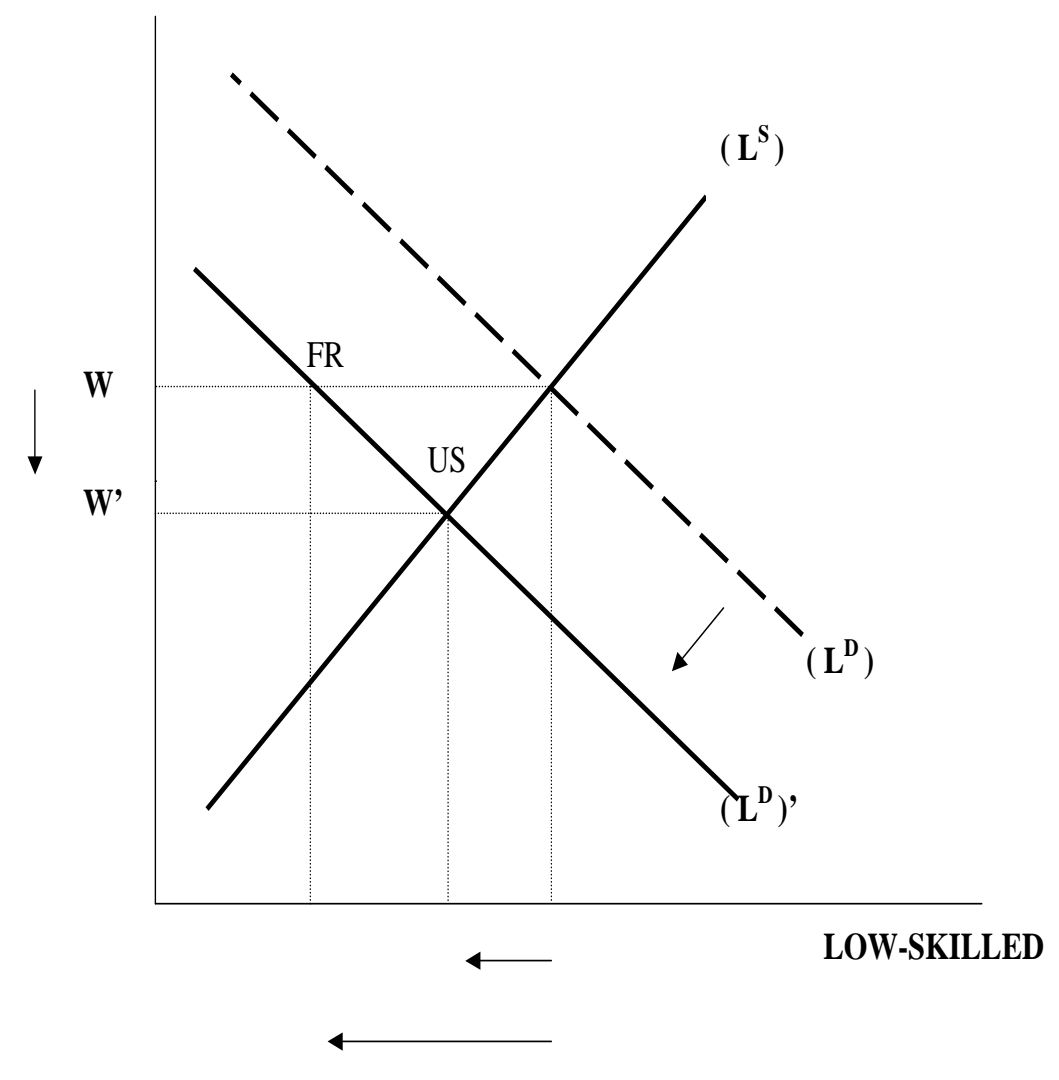

Units are the share of low-skilled individuals who supply their labor, whose labor is demanded, or who are employed in the population of the low skilled, relative to the corresponding shares of the high skilled (x-axis) and the average wage of low skilled relative to the high skilled (y-axis).

Card et al. (1999) and Puhani (2008) formulate the Krugman hypothesis based on a simple static model of labor supply and labor demand with heterogenous labor, where unemployment arises as a disequilibrium phenomenon, as a consequence of the presence of wage-setting institutions that push the relative wages of the lowskilled above their market clearing level. ${ }^{5}$ An alternative strand of research models unemployment as an equilibrium phenomenon, driven by structural characteristics of the labor market (see Pissarides (2000) for the canonical model). Moore and Ranjan (2005) formalize the Krugman hypothesis, in the presence of a skill-biased technological shock as well as a trade shock, in a model of search unemployment

\footnotetext{
${ }^{5}$ See for example Sarantis (1981) for one of the canonical models of disequilibrium unemployment.
} 
extended to an open economy. They specify similar production function to ours, but with only two skill-groups, assume perfectly inelastic labor supply, and, capture the dynamic nature of the labor market via matching. The idea underlying the tradeoff, however, is rather similar: labor market rigidities raise the wage demanded by workers, and therefore shift the wage curve upwards, which increases labor market tightness and results in higher unemployment in response to the same demand shock.

Finally, Gregg and Manning (1997) argue that both strands of literature should formulate the labor supply curve (or the wage curve) as a function of relative rather than absolute level of wages, in order to adequately explain the long-term consequences of skill-biased technological change. They formulate a dynamic model of the labor market, where the labor supply adjusts in response to changes in skillpremium in wages, and where education policies may help the relative supply of skills to keep up with the changes in labor demand. They conclude that, in the long run,

such educational policies are much more important for combating unemployment of the unskilled, as a consequence of the skill-biased technological progress, than labor market institutions.

In this paper, we follow the direction of Card et al. (1999) and Puhani (2008), and use the static model of labor supply and labor demand with heterogeneous labor, which allows us to accommodate annual snapshots of the economy with multiple skill-groups, while taking into account unobserved group-level heterogeneity.

\section{Institutional and Macroeconomic Context}

\subsection{Institutional Background}

Which institutions affect wage flexibility? A comprehensive study by Koeniger, Leonardi, and Nunziata (2007) finds that changes in union density, minimum wage, employment protection, and duration and size of unemployment benefits can explain much of the evolution of male wage inequality in eleven OECD countries between 
1973 and 1998. We discuss the labor market institutions in France, the UK and the US relevant for our study next. Table 1 summarizes the three key institutions that affect wage-setting.

Table 1: Wage-setting Institutions

\begin{tabular}{|l|c|c|c|c|c|c|}
\hline & \multicolumn{2}{|l|}{ TU Density (\%) } & \multicolumn{2}{l|}{ CB Coverage (\%) } & \multicolumn{2}{l|}{ Min to Med Wage (\%) } \\
\hline \hline & 1990 & 2000 & 1990 & 2000 & 1990 & 2000 \\
\hline \hline FR & 10 & 10 & $90+$ & $90+$ & 0.52 & 0.56 \\
UK & 39 & 31 & $40+$ & $30+$ & NA & 0.41 \\
USA & 15 & 13 & 18 & 14 & 0.36 & 0.36 \\
\hline \hline
\end{tabular}

Source: OECD Employment Outlook 2004 and OECD.StatExtracts at http://stats.oecd.org. A + sign represents a lower bound estimate by the OECD. In the UK, a minimum wage was first established in 1999. The three columns represent trade union density, collective bargaining coverage, and minimum to median wage coverage, all in \%.

Although union membership in the UK (39 \%) and the US (15\%), which also coincides with the collective bargaining coverage in the two countries, exceeds that in France $(10 \%)$, it declined over the analyzed period and is in stark contrast with the stable $90 \%$ share of French workers covered by collective bargaining. ${ }^{6}$ Moreover, bargaining is decentralized in the US and the UK, taking place at a plant or company level, whereas in France, part of the bargaining is centralized at an industry level (OECD 2004). Statutory minimum wage was slightly over $50 \%$ of the median wage in France throughout the analyzed period, compared with $36 \%$ in the US. While this ratio reached $41 \%$ in the UK towards the end of the analyzed period, it was zero until 1999, when minimum wage was first established there. As for institutions affecting the flexibility of labor demand, employment protection, as measured by the strictness of employment protection index (with respect to both

\footnotetext{
${ }^{6}$ While union density reveals one aspect of the strength of the unions, bargaining coverage shows the breadth of their impact, i.e. what share of salaried workers are subject to union-negotiated terms and conditions of employment.
} 
individual and collective dismissals) from OECD statistics, was 0.26 in the US and 1.03 in the UK, but 2.34 in France and did not change over the 1990s (OECD 2004).

Figure 2: Wage Inequality

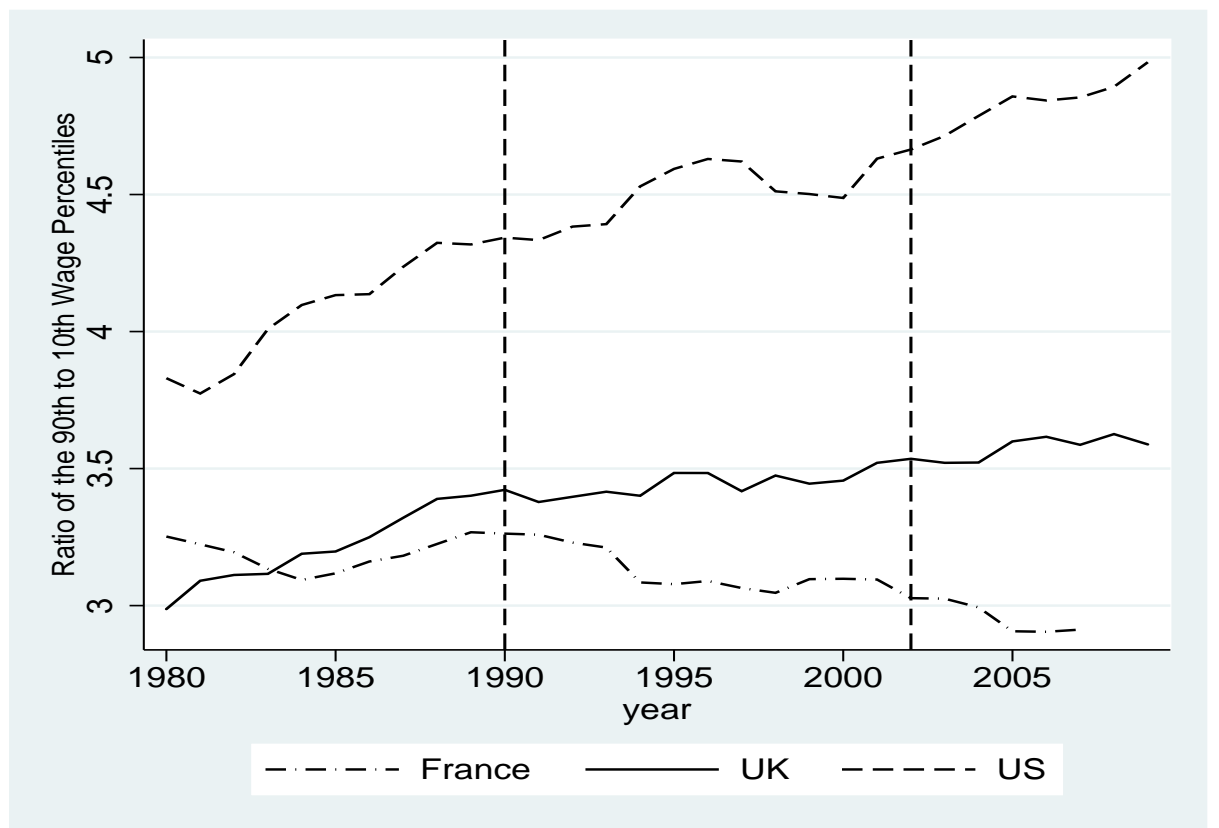

Source: OECD. Vertical lines show the analyzed period except for the UK, which starts in 1993 rather than 1990.

Previous research has already established the link between these institutions and changes in relative wages of men in the three analyzed countries: Increase in minimum wage and stricter employment protection can account for a $15 \%$ reduction in male wage inequality in France between 1973-1998, whereas $13 \%$ increase in male wage inequality in the US and the UK can be explained by the decline in the power of unions and, in the US, also by the decrease in minimum wage (Koeniger, Leonardi, and Nunziata 2007). Moreover, Avouyi-Dovi, Fougere, and Gautier (2013) provide insights into the intermediate step in the relationship between institutions and relative wages in France, revealing how collective bargaining and, in particular, the statutory minimum wage affects wage-setting. Overall, we expect wages in France to be less responsive to the economic shocks than in the US. The degree of flexibility of wages in the UK is less clear, given its historically highest (but declining) union density, wider collective bargaining coverage and stronger employment protection 
Figure 3: Unemployment Rate

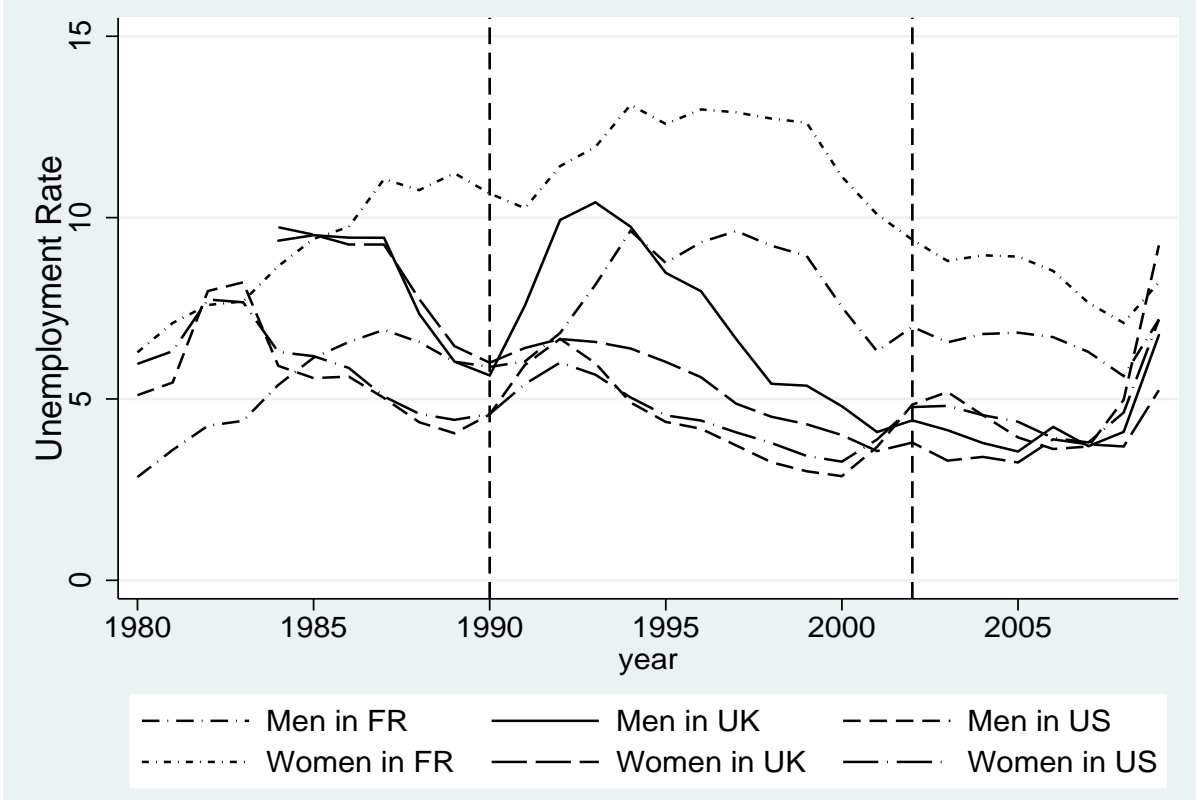

Source: OECD. Out-of-school civilians of age 25-54. Vertical lines show the analyzed period except for the UK, which starts in 1993 rather than 1990.

Figure 4: Labor Force Participation Rate

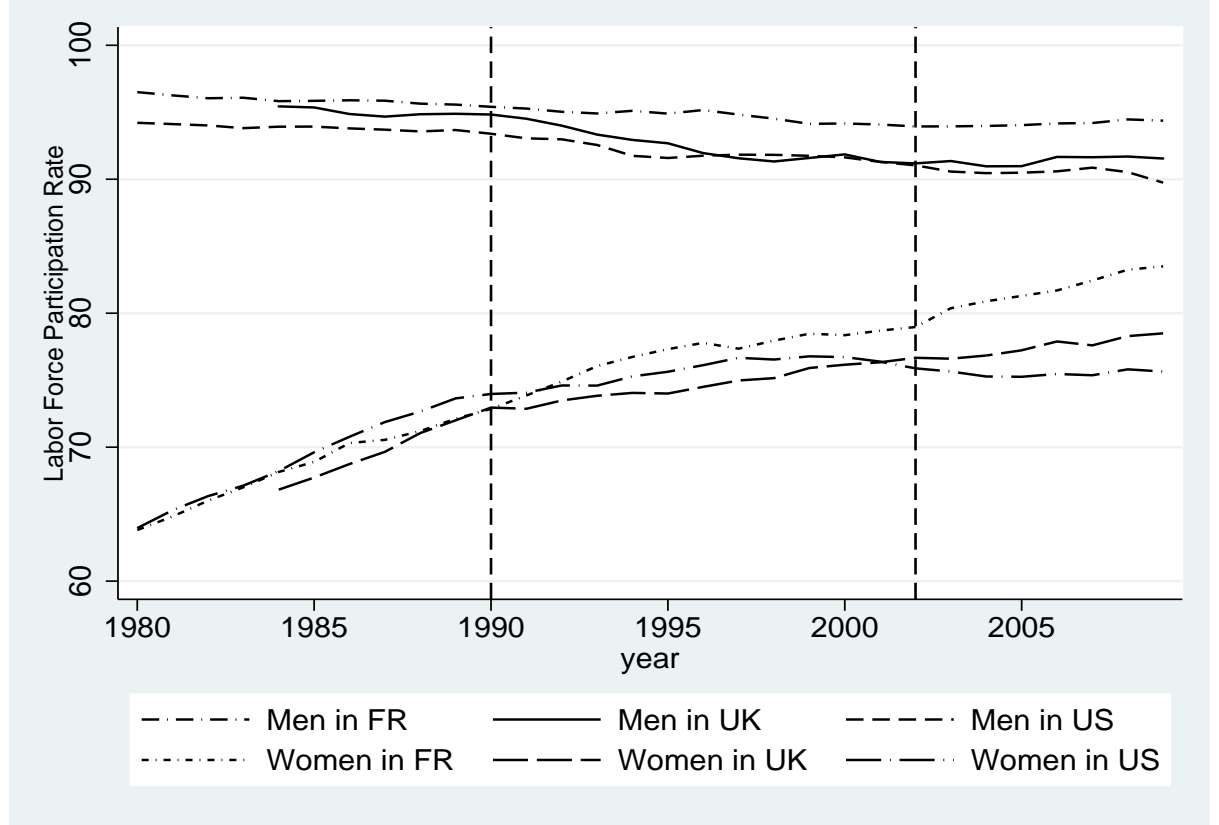

Source: OECD. Out-of-school civilians of age 25-54. Vertical lines show the analyzed period except for the UK, which starts in 1993 rather than 1990. 
than in the US, in contrast with its lack of a statutory minimum wage until 1999.

\subsection{Aggregate Development}

The aggregate development in the three countries over the analyzed period of the 1990s, as presented in Figures 2, 3, and 4, fit the general predictions of the Krugman hypothesis, as well as its extended version. While wage inequality, measured by the 90th to 10th wage percentile, increased sharply in the US (from 4.3 to 4.7 ) and also somewhat in the UK (from 3.4 to 3.5 ), in France, it actually declined (from 3.3 to 3). On the contrary, unemployment was on a steady rise in France over most of the period, but showed a decreased in the US. The recession of 1991-1992 in the UK resulted in a sharp rise in the unemployment rate, in particular among men, at the beginning of the studied period. The long-term trend over 1980s and 1990s in the unemployment rate, however, was that of a slow decline as in the US. ${ }^{7}$ Finally, whereas the long-term trend of rising female labor force participation continued in all three countries over the 1990s, labor force participation of men declined in the US and even more in the UK during the analyzed period. Although the male inactivity rates had an upward trend in all three countries, it increased the least in France and the most in the US.

\section{The Model}

We start with a simple model of labor supply and labor demand with heterogenous labor from Card et al. (1999) and extend it to allow for a wage-elastic labor supply and to describe all three labor force states (employment, unemployment, and inactivity). ${ }^{8}$ We assume that the population is composed of $J$ labor types that differ both in skills and reservation wages. ${ }^{9}$ In the economy, a single homogenous

\footnotetext{
${ }^{7}$ Note that due to data limitations, sample for the UK starts only in 1993.

${ }^{8}$ We discuss the details of our methodological extensions of Card et al. (1999) whenever relevant.

${ }^{9}$ We refer to the different labor types as skill-groups. The empirical analysis defines a skillgroup on the basis of gender, age and education.
} 
good $Y$ is produced from $J$ labor inputs $L_{j}$ according to a constant returns CES production function, as follows

$$
Y=f\left(L_{1}, L_{2}, . . L_{J}\right)=\left(\sum_{j}\left(c_{j} L_{j}\right)^{\frac{\sigma-1}{\sigma}}\right)^{\frac{\sigma}{\sigma-1}}
$$

where $\sigma$ is the elasticity of substitution between any two inputs, and $c_{j}$ is the relative efficiency parameter for skill-group $j$. The labor demand for input $j$, implied by this production function, is

$$
\ln \left(L_{j}^{d}\right)=\ln (Y)-\sigma \ln \left(w_{j}\right)+(\sigma-1) \ln \left(c_{j}\right)
$$

where $w_{j}$ is the wage the economy pays on average to skill-group $j .{ }^{10}$ Divided by $P_{j}$, the total number of individuals in group $j$, and including the error term, the labor demand for skill-group $j$ becomes

$$
\ln \left(l_{j}^{d}\right)=\ln (y)-\sigma \ln \left(w_{j}\right)+(\sigma-1) \ln \left(c_{j}\right)-\ln \left(p_{j}\right)+\nu_{j}^{d}
$$

where $l_{j}^{d}=\frac{L_{j}^{d}}{P_{j}}$ is the proportion of individuals in group $j$ whose labor is demanded, $p_{j}=\frac{P_{j}}{P}$ is the proportion of skill-group $j$ in the total population $P, y=\frac{Y}{P}$ is the per capita output, and $\nu_{j}^{d}$ is the error term in the labor demand equation.

An individual from skill-group $j$ will supply her labor if $w_{j}$, the wage she would on average receive if entering the labor market, exceeds the reservation wage determined by her preferences and her outside options and costs, as given by her marital status and the presence of children. The two factors are expressed in proportions and therefore reflect the typical household characteristics of the individuals from a particular skill-group. The proportion of individuals in group $j$ that supply their labor, $l_{j}^{S}$, can be written in a standard form as

$$
l_{j}^{s}=\frac{L_{j}^{s}}{P_{j}}=w_{j}^{\varepsilon} \exp \left(\alpha_{j}+\beta^{g} m_{j}+\gamma^{g} k_{j}\right)
$$

\footnotetext{
${ }^{10}$ Note that the changes in relative labor demand - the driving force of the rise in wage inequality versus unemployment in the Krugman hypothesis - will be modeled as shocks to the relative efficiency parameters $c_{j}$.
} 
where $\varepsilon$ is the wage elasticity common to all groups, $\alpha_{j}$ is the time-invariant groupspecific heterogeneity in preferences, $m_{j}$ is the proportion of individuals who are married, and $k_{j}$ is the proportion of individuals living in households that include pre-school age children. ${ }^{11}$ The effects of marital status and of the presence of preschool children are allowed to differ by gender, where the superscript $g=f$ for the skill-groups of women, and $g=m$ for the skill-groups of men. Expressed in logarithms, and including the error term $\nu_{j}^{s}$, the labor supply is given by

$$
\ln \left(\begin{array}{l}
s \\
j
\end{array}\right)=\alpha_{j}+\varepsilon \ln \left(w_{j}\right)+\beta^{g} m_{j}+\gamma^{g} k_{j}+\nu_{j}^{s}
$$

The market clearing wage $w_{j}^{*}$ for group $j$ is defined by the equality of the supply and demand

$$
l_{j}^{s}\left(w_{j}^{*}\right) \equiv l_{j}^{d}\left(w_{j}^{*}\right)
$$

and can be expressed as

$$
\ln \left(w_{j}^{*}\right)=\frac{1}{\varepsilon+\sigma}\left[\ln (y)-\alpha_{j}-\beta^{g} m_{j}-\gamma^{g} k_{j}+(\sigma-1) \ln \left(c_{j}\right)-\ln \left(p_{j}\right)+\nu_{j}^{d}-\nu_{j}^{s}\right]
$$

When the market clears, there is no unemployment, and labor force participation rate and the employment rate are equal. ${ }^{12}$ Under the impact of labor market institutions that limit wage flexibility, the actual wage may differ from its market clearing value. Similar to Card. et al (1999), we specify the following relationship between the actual and the market clearing wage for group $j$

$$
\ln \left(w_{j}\right)=\eta+\omega_{j}+\rho \ln \left(w_{j}^{*}\right)+\nu_{j}^{w}
$$

where $\rho \in\langle 0,1\rangle$ is a coefficient of wage flexibility that shows to what extent the actual wage reacts to changes in the market-clearing wage, whereas $\eta$ and $\omega_{j}$

\footnotetext{
${ }^{11}$ Labor supply is measured by labor force participation in this model. In what follows we use the terms labor supply and labor force participation interchangeably.

12 The theoretical model does not consider other sources and types of unemployment. The empirical application however allows for additional time-invariant group-specific and year-specific group-invariant components in the unemployment equation via two way fixed effects.
} 
represent the time-varying group-invariant and the time-invariant group-specific institutional effects, respectively. When the actual wage differs from the marketclearing wage, market does not clear, and the employment rate is determined either by the labor supply or by the labor demand, whichever of the two is smaller.

As in the standard disequilibrium model of unemployment, ${ }^{13}$ employment in group $j$ is given by

$$
e_{j} \equiv \min \left[l_{j}^{d}, l_{j}^{s}\right]
$$

If labor supply exceeds labor demand, proportion of unemployed in the skill-group $j$ is given by

$$
u_{j} \equiv l_{j}^{s}-l_{j}^{d}
$$

Note that, in contrast with the traditional definition of the unemployment rate, $u_{j}$ is defined here as the fraction of the unemployed in the population, rather than in the labor force, of group $j$. Denoting the proportion of inactive in group $j$ as $n_{j}$, we can write down an identity relationship that states that the proportions in the three labor force states in group $j$ must add to one

$$
e_{j}+u_{j}+n_{j} \equiv 1
$$

The model differs from that in Card et al. (1999) in two respects. First, Card et al. (1999) specify only the wage and labor supply equations, and use employment rate for the estimation of the latter, an identity that holds only when wages are perfectly flexible $(\rho=1)$ and the markets clear. ${ }^{14}$ Relaxing the assumption of full wage flexibility leads, as in our model, to a third equation that describes labor supply as observationally distinct from the employment rate. Moreover, this extension allows us to explicitly model unemployment and inactivity, which is crucial for the extended version of the Krugman hypothesis.

Second, we augment the model with the two supply shifters: marital status and

\footnotetext{
${ }^{13}$ See for example equation 1c in Sarantis (1981)

14 This implies that if wages are not perfectly flexible, the estimated coefficients are given an incorrect interpretation.
} 
the presence of pre-school age children, in addition to the population shares that arise in the model only as an implication of the transformation of labor demand equation from levels to proportions.

Similar to Card et al. (1999), we substitute the relative efficiency parameters $c_{j t}$, which are not observed, with a proxy variable $\tilde{c}_{j t}$, assuming that the relationship between the proxy and the unobserved variable is as follows

$$
\ln \left(c_{j t}\right)=\lambda_{0 t}+\lambda \ln \left(\tilde{c}_{j t}\right)+\nu_{j t}^{c}
$$

where $\lambda_{0 t}$ is a time-variant parameter, $\lambda$ describes the mapping from percentage changes in the proxy variable to percentage changes in $c_{j t}$, and $\nu_{j t}^{c}$ is the error term, which is assumed to be independent of the proxy and all other right hand side variables in the three equations. ${ }^{15}$

As a proxy variable for the unobserved relative efficiency measure we use the skill-group's share in the total value added produced in the whole economy of the given country in the previous year. ${ }^{16}$ The information about each individual's industry is employed to map the industry-specific information to the skill-group data. The demand shifter $\tilde{c}_{j t}$ is constructed in the following way

$$
\tilde{c}_{j t}=\ln \left(\sum_{k=1}^{K} \frac{I_{k j t-1}}{I_{k t-1}} S_{k t-1}\right)
$$

where $k$ is the industry identifier, $\frac{I_{k j t-1}}{I_{k t-1}}$ is the fraction of $I_{k j t-1}$, individuals from group $j$ in industry $k$ in year $t-1$, in $I_{k t-1}$, the total number of individuals in industry $k$ in year $t-1$, and $S_{k t}$ is the percentage share of industry $k$ in the total value added in the economy in year $t .{ }^{17}$ The changes in the share of the total value

\footnotetext{
${ }^{15}$ For comparison, Card at al. (1999) write down the following relationship between the relative efficiency term and their proxy: $(\sigma-1) \Delta \ln \left(c_{j t}\right)=\alpha+\beta D_{j}+u_{j}$ where $D_{j}$ is the proxy variable.

${ }^{16}$ Card et al. (1999) use either the initial wage level or the proportion of individuals using a computer at work at the end of the period as the proxy variables for the relative efficiency parameters. Note that these proxies are time-invariant and therefore not suitable for our panel data estimation. Their justification is also pertinent to 1980s rather than 1990s.

${ }^{17}$ The information about the value added shares by industry comes from the OECD STAN database. See Section A.2 of the Appendix for details.
} 
added are likely to be correlated with the changes in the relative efficiency of the skill-group, and in general with the labor demand for the individuals from that group. It can be argued that using the share of a given skill-group in a particular industry to map the industry level shares in the value added to the skill groups may cause our demand shifter to be endogenous. We mitigate this problem by using a lagged value of the share in the value added, as defined above. Moreover, we address the potential endogeneity of our demand shifter in section 6.2. In particular, we check validity of our baseline results by re-estimating (a substantially restricted version of) the model using a country-neutral demand shifter, constructed from the skill-group specific shares in value added from the other two countries than the one for which the estimation is carried.

\section{Estimation}

\subsection{Methodology}

The model described by equations 1 to 7 can be formulated as a system of the four endogenously determined variables (wage $w_{j}$, the proportions of employed $e_{j}$, unemployed $u_{j}$, and inactive $n_{j}$ in group $j$ ), expressed in terms of the four exogenous factors. As the proportion of employed, unemployed, and inactive equal to one, one of the three equations describing the labor force status is redundant. If we express the left-hand-side variables in logarithmic form, and specify an equation for the logarithm of labor supply $\ln \left(\begin{array}{l}s \\ j\end{array}\right)$, that equals $\ln \left(e_{j}+u_{j}\right)$, rather than an equation for unemployment or inactivity, the model can be written as a system of three linear equations. ${ }^{18}$ Adding the time subscripts, the model can be estimated using group-level panel data with group and year fixed effects as follows

\footnotetext{
${ }^{18}$ We use the sum of the share of employed and unemployed to measure labor supply, and the share of employed to measure labor demand. This assumes that employment is determined off the demand curve, which is justified by the non-zero unemployment in every skill-group, suggesting that supply exceeds demand.
} 


$$
\begin{aligned}
\ln \left(w_{j t}\right) & =\pi_{0 t}^{w}+\pi_{1 j}^{w}+\pi_{p}^{w} \ln \left(p_{j t}\right)+\pi_{c}^{w} \ln \left(\tilde{c}_{j t}\right)+\pi_{m}^{g w} m_{j t}+\pi_{k}^{g w} k_{j t}+\xi_{j t}^{w} \\
\ln \left(e_{j t}\right) & =\pi_{0 t}^{e}+\pi_{1 j}^{e}+\pi_{p}^{e} \ln \left(p_{j t}\right)+\pi_{c}^{e} \ln \left(\tilde{c}_{j t}\right)+\pi_{m}^{g e} m_{j t}+\pi_{k}^{g e} k_{j t}+\xi_{j t}^{e} \\
\ln \left(\begin{array}{c}
s \\
j t
\end{array}\right) & =\pi_{0 t}^{s}+\pi_{s j}^{s}+\pi_{p}^{s} \ln \left(p_{j t}\right)+\pi_{c}^{s} \ln \left(\tilde{c}_{j t}\right)+\pi_{m}^{g s} m_{j t}+\pi_{k}^{g s} k_{j t}+\xi_{j t}^{s}
\end{aligned}
$$

where the $\pi$-s are functions of the parameters of the underlying model $(\sigma, \varepsilon, \rho$, $\beta^{f}, \beta^{m}, \gamma^{f}, \gamma^{m}, \lambda, \alpha_{j}, \omega_{j}, \ln \left(y_{t}\right)$, and $\left.\eta_{t}\right)$, and $\xi$-s are functions of some of these parameters and the model error terms $\nu_{j}^{d}, \nu_{j}^{s}$, and $\nu_{j}^{w}{ }^{19}$

While group fixed effects reflect heterogeneity in preferences across groups and the group-specific institutional component affecting the actual wage, year fixed effects capture the aggregate development of the economy over time (changes in $\left.y_{t}\right)$ and the changes in institutions that affect all the skill-groups in the same way (changes in $\eta_{t}$ ). With group and year fixed effects, the present analysis focuses on the within group and year variation in the wage and labor-force-status differentials rather than on their levels. It explores to what extent the relative deviations of the left-hand-side variables from their time and group averages can be explained by the relative deviations of the exogenous factors on the right-hand side. In general, the system has the following form

$$
y_{j t}^{i}=D_{j}^{i}+D_{t}^{i}+x_{j t}^{i} \pi^{i}+\varepsilon_{j t}^{i}
$$

where $j$ and $t$ indicates group and time respectively, $i$ is an indicator for one of the three equations in the system, $y$-s are the three dependent variables, $x$ s are the supply and demand shifters, $D$-s are group and year fixed effects, and $\pi^{i}=\left(\pi_{\tilde{c}}^{i}, \pi_{p}^{i}, \pi_{m}^{f i}, \pi_{m}^{m i}, \pi_{k}^{f i}, \pi_{k}^{m i}\right)$ is a vector of the $\pi$-s defined above. ${ }^{20}$ Note that

\footnotetext{
${ }^{19}$ The $\pi$-s associated with the four exogenous shifters are defined in Table 2, as discussed later. For the definition of $\pi$-s representing group-specific and year-specific effects and $\xi$-s in terms of the parameters and error terms of the underlying model see Section A.4.

${ }^{20}$ When using the data from the UK, which has only 5 education categories and a shorter time span, we define the group fixed effects on a broader age categories than the ones the data are stratified by. Specifically, the six categories are lumped together into three age ranges (25-34, 35-44 and 45-54) for the construction of the fixed effects for the UK. There are therefore only 30
} 
coefficients $\pi_{m}^{g i}$ and $\pi_{k}^{g i}$ (where $\left.i \in w, e, s\right)$ differ by gender $(g=f, m)$, so the corresponding $\pi$-s are gender specific, which is implemented by using interactions between the share of married individuals or the share of individuals with children and a binary indicator for gender. In order to simplify the estimation, the two-way fixed effects are first extracted from the data by appropriate demeaning. Specifically, we estimate the following equation (which is equivalent to 13 with respect to $\pi$-s)

$$
\tilde{y}_{j t}^{i}=\tilde{x}_{j t}^{i} \pi^{i}+\tilde{\varepsilon}_{j t}^{i}
$$

where $\tilde{y}_{j t}^{i}=y_{j t}^{i}-\bar{y}_{j}^{i}-\bar{y}_{t}^{i}+\overline{\bar{y}}^{i}$, with $\bar{y}_{j}^{i}$ and $\bar{y}_{t}^{i}$ denoting the time and group averages respectively, and $\overline{\bar{y}}^{i}$ the overall average of the dependent variable in equation $i$. Similar for $\tilde{x}_{j t}^{i}$ and $\tilde{\varepsilon}_{j t}^{i}$. The three-equation system with equation-specific two-way fixed effects, expressed in deviations and stacked together as described in equation 14 , is estimated by non-linear least squares, where the optimization procedure is carried out with respect to $\sigma, \varepsilon, \rho, \beta^{f}, \beta^{m}, \gamma^{f}, \gamma^{m}$, which enter the system in a non-linear way through $\pi^{i}=\left(\pi_{\tilde{c}}^{i}, \pi_{p}^{i}, \pi_{m}^{f i}, \pi_{m}^{m i}, \pi_{k}^{f i}, \pi_{k}^{m i}\right)$, as defined in Table 2 . The estimation is carried out for each country separately. The three columns of Table 2 describe the three equations for wage, employment and labor supply respectively. When wages are fully flexible $(\rho=1)$, the last two columns are identical and the model reduces from three to two equations, the wage equation and the employment equation. ${ }^{21}$ As in the standard supply and demand model, identification of the underlying parameters requires exclusion restrictions from each equation: First, the group-level family variables $\left(m_{j t}\right.$ and $\left.k_{j t}\right)$ - the supply shifters - are assumed to affect the proportion of individuals who supply their labor in a given skill-group but have no impact on labor demand other than through wage. Second, the share in the value added in the previous year $\left(\tilde{c}_{j t}\right)$ - the demand shifter - is assumed to affect labor supply only through wage). ${ }^{22}$

fixed effects for the 60 skill-groups in the estimation for the UK.

${ }^{21}$ When the labor market clears, there is no unemployment, and the responses of employment and labor supply to shocks are equal.

${ }^{22}$ Identification of the full model is shown in Section A.4.2 in the Appendix. 
Table 2: Definition of $\pi$ Coefficients of the Supply and Demand Factors Parameters

\begin{tabular}{|c|c|c|c|}
\hline$i=w, e, s$ & $\ln \left(w_{j}\right)$ & $\ln \left(e_{j}\right)$ & $\ln \left(l_{j}^{s}\right)$ \\
\hline$\pi_{\tilde{c}}^{i}$ & $\left(\frac{\rho}{\sigma+\varepsilon}\right)(\sigma-1) \lambda$ & $\left(1-\frac{\sigma \rho}{\sigma+\varepsilon}\right)(\sigma-1) \lambda$ & $\frac{\varepsilon \rho}{\sigma+\varepsilon}(\sigma-1) \lambda$ \\
$\pi_{p}^{i}$ & $-\left(\frac{\rho}{\sigma+\varepsilon}\right)$ & $-\left(1-\frac{\sigma \rho}{\sigma+\varepsilon}\right)$ & $-\frac{\varepsilon \rho}{\sigma+\varepsilon}$ \\
$\pi_{m}^{f i}$ & $-\left(\frac{\rho}{\sigma+\varepsilon}\right) \beta^{f}$ & $\left(\frac{\sigma \rho}{\sigma+\varepsilon}\right) \beta^{f}$ & $\left(1-\frac{\varepsilon \rho}{\sigma+\varepsilon}\right) \beta^{f}$ \\
$\pi_{m}^{m i}$ & $-\left(\frac{\rho}{\sigma+\varepsilon}\right) \beta^{m}$ & $\left(\frac{\sigma \rho}{\sigma+\varepsilon}\right) \beta^{m}$ & $\left(1-\frac{\varepsilon \rho}{\sigma+\varepsilon}\right) \beta^{m}$ \\
$\pi_{k}^{f i}$ & $-\left(\frac{\rho}{\sigma+\varepsilon}\right) \gamma^{f}$ & $\left(\frac{\sigma \rho}{\sigma+\varepsilon}\right) \gamma^{f}$ & $\left(1-\frac{\varepsilon \rho}{\sigma+\varepsilon}\right) \gamma^{f}$ \\
$\pi_{k}^{m i}$ & $-\left(\frac{\rho}{\sigma+\varepsilon}\right) \gamma^{m}$ & $\left(\frac{\sigma \rho}{\sigma+\varepsilon}\right) \gamma^{m}$ & $\left(1-\frac{\varepsilon \rho}{\sigma+\varepsilon}\right) \gamma^{m}$ \\
\hline
\end{tabular}

Note: While all parameters are identified, convergence is achieved only when $\lambda$ is restricted to equal 1. This restriction implies that one percentage change in the group $j$ 's relative efficiency is equal to one percentage change in the group $j$ 's share in the value added produced in the economy in the previous year. See A.4.3 for detailed discussion.

\subsection{Standard Errors}

The fact that the group-level variables are constructed from the individual-level data, builds into the model a particular type of group-wise heteroskedasticity, as the variance of the within-group-averaged individual error term varies with the sample size. In addition, the binary nature of the employment and labor force participation indicators further implies a specific form of heteroskedasticity present in the loglinear models of the proportion data. Standard errors are therefore based on the panel-robust sandwich-type covariance matrix that allows for heteroskedasticity, serial correlation, as well as the cross-equation correlation of unknown forms, but assumes independence of the error terms across the groups (i.e. over $j$ ). ${ }^{23}$

\footnotetext{
${ }^{23}$ The robust covariance matrix is calculated as follows $\hat{V}(\hat{\beta})=\left(\tilde{X}^{\prime} \tilde{X}\right)^{-1} \tilde{X} \tilde{v} \tilde{v}^{\prime} \tilde{X}^{\prime}\left(\tilde{X}^{\prime} \tilde{X}\right)^{-1}$ where $\tilde{v}_{j t}^{i}=\tilde{y}_{j t}^{i}-\tilde{x}_{j t}^{i} \hat{\beta}$ and $\tilde{X}$ is a $3 K \times 3 T J$ matrix of the $K$ elements of $\tilde{x}_{j t}^{i}$ for each of the three equations stacked for all $T$ years and $J$ skill groups.
} 


\subsection{Tests of the (Extended) Krugman Hypothesis}

The test of the Krugman hypothesis is based on the cross-country comparison of the estimate of the parameter describing wage flexibility: a value of $\rho$ which is higher in the US and the UK when compared to France, would support the relevance of the Krugman hypothesis for the explanation of the diverse development of wages and unemployment across skills in the three countries. A previous version of this paper also used a series of tests based on the direct estimates of $\pi$-s, the coefficients from the reduced-form estimation of equation 14, similar in spirit to the tests carried out in Card et al. (1999). In order to keep the size of the paper manageable, these were omitted. ${ }^{24}$ As discussed earlier, the reduced-form tests, as well as those based on simple correlations as in Puhani (2008), implicitly assume the same underlying parameters, i.e. the same slopes and shapes, of the labor supplies and labor demands across the compared countries. The results of these tests may therefore be driven by cross-country differences in elasticity of substitution across skill-groups or in wage elasticity of labor supply, rather than by wage rigidity, a fact that may also partly explain the mixed results these tests delivered in the previous studies. Finally, to confirm the relevance of the extended Krugman hypothesis, the estimates of $\varepsilon$, the wage elasticity of labor supply, must be positive and significant.

\subsection{Data}

We construct the panel of the group-level data from the series of national labor force surveys: Enquête Emploi (1990-2002) for France, Labor Force Survey (1993-2002) for the UK, and the March CPS (1990-2002) for the US. There are 72 skill-groups (60 for the UK) defined in each dataset. The skill-groups are based on gender, five age ranges (25-29, 30-34, 35-39, 40-44, 45-49 and 50-54) and six education categories

\footnotetext{
${ }^{24}$ See Bicakova (2006), the working paper version of this study, for the reduced-form estimation results of the baseline model, as well as for the tests of the Krugman hypothesis and its extended version based on the reduced-form coefficients. The results of these tests are broadly consistent with those presented here.
} 
in France and the US, and five education categories in the UK. ${ }^{25}$

We construct the share of individuals, who are employed, who are in the labor force, who are married, and who have small children in each skill group, weighted by the appropriate sampling weights. The population share is the share of a particular group in the total population of prime age individuals. Finally, we use median hourly wage for each skill group. In order to take into account selection into employment, we construct the median from the real hourly wages of all individuals in the group, using imputed wages for individuals with missing wage information. ${ }^{26}$

\section{Results}

\subsection{Baseline Model}

The baseline results, presented in Table 3, suggest that wages are not perfectly flexible in any of the three countries. Given the size of the coefficients and their standard errors, the hypothesis that $\rho=1$ is rejected in all three cases. The estimated value of $\rho$ of 0.796 for France, 0.835 for the US, and 0.842 for the UK confirm the Krugman hypothesis. Although the differences between France and the other two countries are not huge, they are still important and statistically significant. ${ }^{27}$ The asymptotic t-statistics for the difference between France and the US is 2.01 (significant at $5 \%$ ), while it is 2.58 (significant at $1 \%$ ) for the difference between France and the UK. The difference between the coefficients for the UK and the US is not significant.

\footnotetext{
${ }^{25}$ Group classification is chosen so as to keep a reasonable size of all the skill-groups over all the years. The group sample size is never smaller than 150 individuals. The data is described in Section A.2 in the Appendix.

${ }^{26}$ See section A.3 in the Appendix for details. As part of the sensitivity analysis, we use the median of the observed wages, and also alternate medians with means. The estimates do not qualitatively differ from those presented here (see Bicakova 2006).

${ }^{27}$ Comparing France to the US, two countries with similar estimates of $\sigma$ and $\varepsilon$, the difference in the estimated parameter of wage flexibility implies that wages decrease by 0.2 p.p. more in response to $10 \%$ decline in the demand shocks in the US than in France, whereas employment in the US decreases by 0.4 p.p. less than in France.
} 
The values of $\sigma$, the elasticity of substitution between different skill-groups, are in the range found in previous research and close to the widely-accepted value of 1.4 for the substitution between high-skilled and low-skilled in the US (Katz and Murphy 1992). The extended version of the Krugman hypothesis also finds supporting evidence, as $\varepsilon$, wage elasticity of labor supply, is positive and significant in all three countries. Labor supply in the UK seems more sensitive to wages than in the other two countries, implying that even small decline in wages may result in non-negligible increases in inactivity there.

Table 3: Baseline Results

\begin{tabular}{lllllll}
\hline \hline & \multicolumn{2}{c}{ FR } & \multicolumn{2}{c}{ US } & \multicolumn{2}{c}{ UK } \\
\hline \hline$\rho$ & $0.796^{* *}$ & $(0.011)$ & $0.835^{* *}$ & $(0.016)$ & $0.842^{* *}$ & $(0.014)$ \\
$\sigma$ & $1.893^{* *}$ & $(0.033)$ & $1.889^{* *}$ & $(0.066)$ & $2.249^{* *}$ & $(0.086)$ \\
$\varepsilon$ & $0.145^{*}$ & $(0.060)$ & $0.145^{*}$ & $(0.065)$ & $0.282^{* *}$ & $(0.089)$ \\
$\beta^{f}$ & 0.017 & $(0.130)$ & 0.114 & $(0.147)$ & -0.024 & $(0.079)$ \\
$\beta^{m}$ & $0.479^{* *}$ & $(0.098)$ & $0.147^{\dagger}$ & $(0.088)$ & $-0.101^{*}$ & $(0.040)$ \\
$\gamma^{f}$ & $-0.207^{*}$ & $(0.090)$ & $-0.460^{* *}$ & $(0.168)$ & $-0.319^{* *}$ & $(0.051)$ \\
$\gamma^{m}$ & -0.008 & $(0.067)$ & $0.414^{* *}$ & $(0.155)$ & $0.063^{*}$ & $(0.025)$ \\
\hline
\end{tabular}

Significance levels : $\quad \quad \quad$ : $10 \% \quad *: 5 \% \quad * *: 1 \%$

Note: Parameters were estimated by non-linear least squares applied to the system of the three equations 10, 11, and 12, with the $\pi$ parameters defined as in Table 2. Standard errors in parentheses. The sample size is 936 (600 in the UK) group-year observations. 12 (10 in the UK) year effects and 72 (60 in the UK) group fixed effects were included via initial demeaning.

As expected, the presence of pre-school children has a negative effect on female labor supply in all three countries, with the highest effect in the US and the lowest in France. In accord with this ranking, pre-school children have a positive effect on male labor supply in the US and the UK but none in France. We expect this variation to be driven by cross-country differences in preferences and, in particular, in the cost of child care. Somewhat surprisingly, being married does not seem to affect female labor supply, though it increases the labor supply of men in France and the US but decreases it in the UK. We acknowledge that exogeneity of marital status and children may be questioned, as family formation and fertility decisions 
are often themselves affected by the situation in the labor market (Adsera 2005). We explore this potential source of bias by re-estimating the model with the population shares of the respective groups as the only supply shifter. The results remain almost the same, with $\rho$ equal to 0.796 in France, 0.833 in the US, and 0.834 in the UK. ${ }^{28}$ More importantly, as discussed earlier, our demand shifter may also violate the exogeneity assumption due to the way the industry-level shares in the value added are mapped into the skill-group shares. We explore the robustness of our results with respect to this potential source of bias next.

\subsection{Exogeneity of the Demand Shifter}

The demand shifter in our model is the skill-group share in the total value added produced in the economy in a previous year, as defined by equation 9 . As the estimation includes skill-group and year fixed effects, the underlying assumption we make is the following: the "change" (deviation from the skill-group mean and aggregate annual mean) in the share of a given skill-group in the previous year has impact on the current "changes" in the skill-groups' average wage, employment, and labor supply but is itself unaffected by them (or by the current change in any of their other unobserved determinants). If this assumption does not hold, our estimate may be biased. In order to check the validity of the baseline results, we re-estimate (a substantially restricted version of) the model using a countryneutral demand shifter, based on data from the other two countries. Specifically, we construct the skill-group share of the value added in the previous year for a given country as the average of the demand shifter for the same group in the remaining two countries. ${ }^{29}$ The country-neutral demand shifter should capture the universal change in the demand for the different skills and, at the same time, be orthogonal to the development of wages, employment and labor supply in a country for which the model is estimated. The biggest challenge of this exercise is that the definition of the skill-groups, specifically the classification of education, is not directly comparable

\footnotetext{
${ }^{28}$ For the complete set of estimates see the working paper Bicakova (2006).

${ }^{29}$ This approach is based on a (substantially simplified) idea from Cutler and Gruber (1996)
} 
across countries. ${ }^{30}$ In order to ensure that we assign the shares in the value added to skill-groups that are comparable across countries, we use a substantially higher level of skill-group aggregation. The new classification of education broadly corresponds to the three levels of education (primary, secondary, and tertiary), while preserving a similar size of the three educational groups in the population across the three countries. $^{31}$ This level of aggregation results in about $50 \%$ reduction of the size of our samples, with only 36 skill groups and 432 (360 in the UK) group-year observations available for the estimation. We therefore estimate the model in its simplest form - with only three key parameters $(\rho, \sigma$, and $\varepsilon)$ - using the share in the population and the country-neutral demand shifter as the right hand side variables (together with skill-group and year effects). ${ }^{32}$

Table 4: Results with Country-Neutral Demand Shifter

\begin{tabular}{ccccccc}
\hline \hline & \multicolumn{2}{c}{ FR } & \multicolumn{2}{c}{ US } & \multicolumn{2}{c}{ UK } \\
\hline \hline$\rho$ & $0.722^{* *}$ & $(0.019)$ & $0.781^{* *}$ & $(0.036)$ & $0.877^{* *}$ & $(0.012)$ \\
$\sigma$ & $1.522^{* *}$ & $(0.154)$ & $1.555^{* *}$ & $(0.072)$ & $2.549^{* *}$ & $(0.181)$ \\
$\varepsilon$ & -0.055 & $(0.036)$ & 0.057 & $(0.060)$ & 0.010 & $(0.061)$ \\
\hline
\end{tabular}

Significance levels : $\quad \dagger: 10 \% \quad *: 5 \% \quad * *: 1 \%$

Note: Parameters were as in Table 3 but with a country-neutral demand shifter and at a higher level of aggregation. Standard errors in parentheses. 432 (360 in the UK) group-year observations. 12 (10 in the UK) year effects and 36 group fixed effects included via initial demeaning.

The results, presented in Table 4, confirm our previous findings, providing further evidence in favor of the Krugman hypothesis, with the wage flexibility parameter equal to 0.72 in France, 0.78 in the US and as much as 0.88 in the UK. Comparison with the baseline results suggests that the country-specific demand shifter may bias the parameter of wage flexibility, as well as the elasticity of substi-

\footnotetext{
${ }^{30}$ Using the ISCED classification, as described in A.2, results in extremely diverse distribution of individuals across the different educational categories among the three countries. Given the differences in educational systems, the skill content of ISCED categories is also likely to differ.

${ }^{31}$ See section A.2 in Appendix for the exact definition of the three levels in the three countries.

${ }^{32}$ The three parameters were, again, estimated by non-linear least squares, applied to equation 14, with the corresponding $\pi$ parameters defined in the first two rows of Table 2 .
} 
tution, upwards, at least in France and the US. ${ }^{33}$ The difference in the estimates, however, may be also driven by the fact that the country-neutral demand shifter does not capture the country-specific changes in the relative demand across skillgroups. The main difference between the baseline results and the ones with countryneutral demand shifter are the estimates of $\varepsilon$, wage elasticity of labor supply, which are no longer significant at this level of aggregation.

Having checked the validity of our results using a country-neutral demand shifter, we continue with the baseline model as our preferred specification - with narrower definition of the skill-groups, larger sample size, and a measure of demand shifters that reflects country specific (rather than overall) developments.

\subsection{Wage Flexibility across Skill Distribution}

While minimum wages increase wage rigidity at the bottom of the wage distribution, collective bargaining has impact at all wage levels. In this section, we focus separately on skill-groups at different positions of the wage distribution in order to disentangle the diverse effects of the two wage-setting institutions. We re-estimate the baseline model for the subsets of skill-groups that correspond to the three broad educational levels (primary, secondary, and tertiary), as defined in the previous section. ${ }^{34}$ The estimates of the wage flexibility parameter by the three different levels are presented in Table 5 .

The greatest cross-country differences in wage flexibility are at the bottom of the wage distribution, revealing that wages are the most rigid among the least skilled. The ranking of the countries according to the wage flexibility parameter is in line with the effective impact of the minimum wage across the three countries, measured as relative to the median wage, as presented in the institutional background section in Table 1, and with the absence of the statutory minimum wage in the UK over the

\footnotetext{
${ }^{33}$ While the results of the two specifications are not directly comparable due to the additional two supply shifters in the baseline model, the results from the baseline model with only three parameters, mentioned earlier in the text and presented in Bicakova (2006), are almost identical to those in Table 3.

${ }^{34}$ See Appendix A.2 for details.
} 
Table 5: Wage Flexibility $\rho$ by Level of Education

\begin{tabular}{lllllll}
\hline \hline$\rho$ & \multicolumn{2}{c}{ FR } & \multicolumn{2}{c}{ US } & \multicolumn{2}{c}{ UK } \\
\hline \hline Primary & $0.736^{* *}$ & $(0.045)$ & $0.827^{* *}$ & $(0.028)$ & $0.956^{* *}$ & $(0.018)$ \\
Secondary & $0.818^{* *}$ & $(0.011)$ & $0.828^{* *}$ & $(0.030)$ & $0.802^{* *}$ & $(0.028)$ \\
Tertiary & $0.822^{* *}$ & $(0.011)$ & $0.857^{* *}$ & $(0.017)$ & $0.821^{* *}$ & $(0.020)$ \\
\hline
\end{tabular}

Significance levels : $\quad \dagger: 10 \% \quad *: 5 \% \quad * *: 1 \%$

Note: The parameters were estimated as in Table 3, but separately for subsets of skill-groups, which broadly correspond to skill-groups with primary, secondary and tertiary education.

Standard errors in parentheses.

two-thirds of the sample period (until 1999). The fact that there are no substantial cross-country differences for the secondary and tertiary level of education, suggests that minimum wages contribute to wage rigidity more than the broad collective bargaining coverage in France. ${ }^{35}$ As for the other parameters (not presented here), the elasticity of substitution increases with educational level, implying that university graduates of different age and gender are closer substitutes than individuals with less than secondary education, where the blue-collar jobs and the required physical skills are likely to be much more specialized by gender, as well as age. Wage elasticity of labor supply, on the other hand, declines with education in the US and the UK, but increases in France. ${ }^{36}$

While the results from the estimation of the baseline model by the three education levels provide additional insights, pointing at minimum wage as the main source of wage rigidity, they should be interpreted with caution, as they focus only on a subset of the labor market within the same broadly-defined skill level, ignoring any relative developments across the three education levels. Moreover, the sample sizes are much smaller, as the number of the skill-groups within each education level is about one third of the number of groups in the baseline model.

\footnotetext{
${ }^{35}$ The only exception is that the US wages at the tertiary level of education are more flexible than in the other two countries, which is in line with the fact that the US has the highest wage inequality at the top of the distribution.

${ }^{36}$ Detailed estimation results are available from the author upon request.
} 


\subsection{Gender-specific Wage Elasticity of Labor Supply}

In this section, we explore the one parameter which is crucial for the proposed extension of the Krugman hypothesis - the wage elasticity of labor supply. While the baseline results provide evidence for wage elastic labor supply, with wage elasticity ranging between 0.145 in France and the US and 0.282 in the UK, the baseline model is fairly restrictive in assuming $\varepsilon$ to be the same across gender, despite the wide empirical evidence that female labor supply is more elastic than that of men. We next extend the baseline model to allow wage elasticity of labor supply to differ across gender. We add a $g$ superscript to $\varepsilon$, the wage elasticity of labor supply, in equation 2 and adjust the model accordingly. Note that this results in all the coefficients in equation 14 to vary by gender, which is implemented by using full interactions between gender and the four right-hand-side variables.

Table 6: Gender-specific Wage Elasticity of Labor Supply

\begin{tabular}{lcccccc}
\hline \hline & \multicolumn{2}{c}{ FR } & \multicolumn{2}{c}{ US } & \multicolumn{2}{c}{ UK } \\
\hline \hline$\rho$ & $0.797^{* *}$ & $(0.010)$ & $0.834^{* *}$ & $(0.016)$ & $0.847^{* *}$ & $(0.014)$ \\
$\sigma$ & $1.904^{* *}$ & $(0.033)$ & $1.881^{* *}$ & $(0.065)$ & $2.268^{* *}$ & $(0.084)$ \\
$\varepsilon^{f}$ & $0.276^{* *}$ & $(0.100)$ & $0.253^{*}$ & $(0.102)$ & $0.464^{* *}$ & $(0.126)$ \\
$\varepsilon^{m}$ & 0.002 & $(0.043)$ & 0.003 & $(0.044)$ & $0.114^{\dagger}$ & $(0.060)$ \\
$\beta^{f}$ & -0.045 & $(0.137)$ & 0.133 & $(0.147)$ & 0.025 & $(0.077)$ \\
$\beta^{m}$ & $0.462^{* *}$ & $(0.091)$ & 0.127 & $(0.077)$ & $-0.123^{* *}$ & $(0.038)$ \\
$\gamma^{f}$ & $-0.221^{*}$ & $(0.091)$ & $-0.454^{*}$ & $(0.173)$ & $-0.348^{* *}$ & $(0.051)$ \\
$\gamma^{m}$ & -0.010 & $(0.053)$ & $0.385^{* *}$ & $(0.142)$ & $0.068^{* *}$ & $(0.024)$ \\
\hline
\end{tabular}

Significance levels : $\quad \quad \quad: 10 \% \quad *: 5 \% \quad * *: 1 \%$

Note: The parameters were estimated by non-linear least squares applied to the extended model, which allows $\varepsilon$ differ by gender. Standard errors in parenthesis. Sample size and fixed effects are the same as in Table 3 .

The results from the extended model, presented in Table 6, are almost identical to the baseline results, with the exception of the wage elasticity of labor supply, which is now estimated separately by gender. In line with widely-established evidence, female labor supply is substantially more elastic than that of men in all three countries. Female wage elasticity of labor supply is about 0.25 in France, 0.28 in 
the US, and almost twice as high in the UK (0.46). While the wage elasticity of labor supply of men is about 0.1 in the UK and significant at $10 \%$ confidence level, the labor supply of men in France and the US is wage inelastic.

Somewhat surprisingly, the estimated sensitivity of labor supply to wages for both women and men in the UK is substantially higher than in the other two countries. $^{37}$ In a recent overview study of labor supply elasticities in the US and Europe, Bargain, Orsini, and Peichl (2012) show that labor force participation elasticities of single women and single men in the UK are the fourth highest, reaching values between 0.26 and 0.35 in 1998, in contrast with elasticities below 0.2 for the comparable groups in France and the US, and much smaller and similar values for married individuals in these three countries. ${ }^{38}$ Given the relatively high share of single individuals in the UK, in particular among the least skilled, which are typically the most wage responsive, the difference between the estimated wage elasticity in the UK and the other two countries seems in line with evidence from other studies. ${ }^{39}$

The estimates of wage elasticity of labor supply, presented in Table 6, suggest that the extended version of the Krugman hypothesis is more relevant for women, and men in the UK, than for men in the other two countries. Having said that, there is evidence that wage elasticity of labor force participation is the highest among the low-skilled (Bargain et al. 2012). As our estimates of wage elasticity of labor supply are averaged across education and age, the potentially wage-elastic labor supply of the least-skilled men may be averaged out. The negative relationship between the wage elasticity of labor supply and the level of skill in the US and the UK was partly confirmed by the estimation results carried out by skill-groups in section

\footnotetext{
${ }^{37}$ The high wage-elasticity of labor supply is also apparent from the baseline results, where the gender-neutral wage elasticity of labor supply in the UK is twice as high as in France and the US.

${ }^{38}$ Note, however, that the fact that we estimate labor supply aggregated at a group level means that the actual magnitudes of our estimates are not directly comparable to those from the micro studies that estimate individual labor supply, such as in Bargain et al. (2012) and the references therein.

${ }^{39}$ The share of single individuals in a given skill-group reach almost $80 \% \%$ in the UK, compared to $60 \%$ in the US and 50\% in France in 2000 among the groups with the highest share of single individuals.
} 
6.3. However, as these results are based only on the subsets of skill-groups, we treat them as supportive evidence rather than a test of the extended version of the Krugman hypothesis. We therefore conclude, based on the estimates of wage elasticity of labor supply across different specification, that while the documented rise in inactivity of men in the UK is likely to be a consequence of the deterioration of the relative wages of the low-skilled, the increase in male inactivity in the US seems to have been driven by other factors.

\section{Conclusion}

The Krugman hypothesis states that high wage inequality in the US and the UK and high unemployment in countries of continental Europe are the consequence of the same negative change in the demand for the low skilled under different degree of wage rigidity. This paper finds support for the Krugman hypothesis, as an explanation of the diverse labor market developments in the UK, the US and France during the 1990s. The results, which are robust to a variety of specifications, including a country-neutral demand shifter, confirm that wages in France are less flexible than wages in the US and the UK. Additional robustness checks reveal that the cross-country differences in wage flexibility are the strongest at the bottom of the wage distribution, suggesting that wage rigidity in France is predominantly driven by its high minimum wage rather than by the broad coverage of collective bargaining. We conclude that while minimum wage in France prevented wage inequality from rising but increased unemployment over 1990s, wage flexibility in the US and the UK maintained unemployment of the low-skilled at lower levels but resulted in higher wage dispersion.

We also propose and find support for the extended version of the trade-off hypothesis, which states that, if labor supply is not perfectly wage inelastic, the rise in wage inequality in countries with flexible wages is likely to be accompanied by an increase in inactivity rates among the low skilled. It follows that the trade-off that 
the policy-makers face is between unemployment, on one hand, and wage inequality and inactivity, on the other. When skill-biased shocks reduce employment of the low-skilled whether wages are rigid or flexible, either through increase in unemployment or rise in inactivity (even if more so in the first case), the decisions affecting wage-setting institutions in order to mitigate these shocks should be accompanied by measures increasing the work incentives for the low-skilled as well as by active labor market policies enhancing their employment. 


\section{References}

Adsera, A. 2005. "Vanishing Children: From High Unemployment to Low Fertility in Developed Countries." American Economic Review 95, no. 2.

Avouyi-Dovi, S., D. Fougere, and E. Gautier. 2013. "Wage Rigidity, Collective Bargaining, and the Minimum Wage: Evidence from French Agreement Data." The Review of Economics and Statistics 95, no. 4.

Bargain, O., K. Orsini, and A. Peichl. 2012. "Comparing Labor Supply Elasticities in Europe and the US: New Results." Iza discussion papers 6735, Institute for the Study of Labor (IZA).

Bertola, G., F. Blau, and L. Kahn. 2007. "Labor market institutions and demographic employment patterns." Journal of Population Economics 20, no. 4 .

Bicakova, A. 2006. "Market vs. Institutions: The Trade-off Between Unemployment and Wage Inequality Revisited." Economics working papers ECO2006/31, European University Institute.

Blank, R. M. 1997. "Is There a Trade-off between Unemployment and Inequality? No Easy Answers: Labor Market Problems in the United States versus Europe." Economics public policy brief 33, The Levy Economics Institute.

Card, D., F. Kramarz, and T. Lemieux. 1999. "Changes in the Relative Structure of Wages and Employment: A Comparison of the United States, Canada, and France." Canadian Journal of Economics 32, no. 4.

Cutler, D. M., and J. Gruber. 1996. "Does Public Insurance Crowd Out Private Insurance?" The Quarterly Journal of Economics 111, no. 2 (May).

Fitzenberger, B., and A. Garloff. 2008. "Unemployment, Labor Market Transitions, And Residual Wage Dispersion." Scottish Journal of Political Economy 55, no. 5 . 
Gregg, P., and A. Manning. 1997. "Skill-biassed change, unemployment and wage inequality." European Economic Review 41, no. 6.

Kahn, L. M. 2000. "Wage Inequality, Collective Bargaining, and Relative Employment from 1985 to 1994: Evidence From Fifteen Oecd Countries." The Review of Economics and Statistics 82, no. 4.

Katz, L. F., and K. M. Murphy. 1992. "Changes in Relative Wages, 1963-1987: Supply and Demand Factors." The Quarterly Journal of Economics 107, no. 1.

Koeniger, W., M. Leonardi, and L. Nunziata. 2007. "Labor Market Institutions and Wage Inequality." Industrial and Labor Relations Review 60, no. 3.

Krugman, P. 1994. "Past and Prospective Causes of High Unemployment." Economic Review, no. Q IV.

Moore, M. P., and P. Ranjan. 2005. "Globalisation vs Skill-Biased Technological Change: Implications for Unemployment and Wage Inequality." Economic Journal 115, no. 503.

OECD. 2004. Employment Outlook 2004. OECD Publishing, Paris.

Oesch, D. 2010. "What Explains High Unemployment among Low-skilled Workers? Evidence from 21 OECD Countries." European Journal of Industrial Relations 16, no. 1 .

Olivetti, C., and B. Petrongolo. 2008. "Unequal Pay or Unequal Employment? A Cross-Country Analysis of Gender Gaps." Journal of Labor Economics 26, no. 4 .

Pissarides, Ch. A. 2000. Equilibrium Unemployment Theory. 2nd Edition. The MIT Press.

Puhani, P. A. 2008. "Transatlantic Differences in Labour Markets: Changes in Wage and Non-Employment Structures in the 1980s and the 1990s." German Economic Review, vol. 9. 
Sarantis, N. C. 1981. "Employment, labor supply and real wages in market disequilibrium." Journal of Macroeconomics 3, no. 3.

Steedman, Hilary, and Steven McIntosh. 2001. "Measuring Low Skills in Europe: How Useful Is the ISCED Framework?" Oxford Economic Papers 53, no. 3. 


\section{A Appendix}

\section{A.1 List of Data Sources}

- Current Population Survey, March CPS Supplement, Bureau of Census and Bureau of Labor Statistics, USA

- Labor Force Survey, the UK Data Archive

- Enquête Emploi, INSEE and LASMAS-IdL, France

- OECD Statistical Database, Statistics Portal, Labor Force Statistics Data and Indicators, http://www.oecd.org/

- STAN Indicators Database (2004), Source OECD, Paris

- Institut national de la statistique et des études économiques, Paris, France, http://www.insee.fr/

- National Statistics, UK, http://www.statistics.gov.uk/statbase/

- Bureau of Economic Analysis, USA, http://www.bea.gov/

\section{A.2 Data Description and Sources}

The three national labor force surveys used in the present analysis are Enquête Emploi (1990-2002) for France, Labor Force Survey (1993-2002) for the UK, and the March CPS (1990-2002) for the US. ${ }^{40}$ The sample consists of the non-institutionalized population between the ages of 25 and 54, excluding students, conscripts and individuals in the Armed Forces. We use information about individuals labor market outcomes collected in the spring of each year in France and the US. Wage information in the UK is collected for different subsets of the households throughout the whole year. The sample size and the size of the skill-groups is summarized in Table A.1.

Education is classified to best fit the country-specific characteristics of the education system, as well as to produce reasonably large group-sizes over the entire period. In the

\footnotetext{
${ }^{40}$ Missing wage information in earlier years of the LFS for the UK requires the analysis to start in 1993 for this country.
} 
Table A.1: The Sample and Skill-Group Size Statistics

\begin{tabular}{|c|c|c|c|c|c|c|}
\hline country & years & $\begin{array}{c}\text { individual obs } \\
\text { (all years) }\end{array}$ & $\begin{array}{c}\text { no. of skill } \\
\text { groups }\end{array}$ & $\begin{array}{c}\text { group obs } \\
\text { (all years) }\end{array}$ & $\begin{array}{c}\text { smallest } \\
\text { group size }\end{array}$ & $\begin{array}{c}\text { largest } \\
\text { group size }\end{array}$ \\
\hline FR & $1990-2002$ & 934719 & 72 & 936 & 150 & 2704 \\
UK & $1993-2002$ & 458107 & 60 & 600 & 168 & 2096 \\
USA & $1990-2002$ & 864323 & 72 & 936 & 176 & 3196 \\
\hline
\end{tabular}

UK the classification is as follows: $1=$ "CSE below grade 1 or equivalent" (less than Olevels), 2 = "GCSE A-C or equivalent" (less than A-levels), $3=$ "A level or equivalent", $4=$ "higher education, below degree", 5 = "degree or higher". In France it is: 1 = "CEP or less" (primary), 2 = "BEPC" (junior high school), 3 = "CAP, BEP" (vocational or technical school) , 4 = "Baccalauréat" (academic high school), $5=$ "undergraduate degree", $6=$ "graduate degree". In the US, it is: 1 = "8th grade or below", 2 = "up to 12 th grade, no diploma", 3 = "high-school graduate or equivalent", 4 = "some college but no degree, Associate's degree in college", $5=$ "Bachelor's Degree", $6=$ "Master's Degree and above". For the estimation of the additional results in sections 6.2 and 6.3, the cruder but cross-country comparable classification of education is defined - in terms of the country-specific classification listed above - as follows: primary (less than secondary) education corresponds to group 1 in France and the UK and 1 and 2 in the US, secondary education to groups $2-4$ in France, 2 and 3 in the UK and 3 and 4 in the US, and tertiary education corresponds to groups 5 and 6 in France and the US and 4 and 5 in the UK. The lowest category is narrower in France and the UK than the definition of the low-skilled suggested by Steedman and McIntosh (2001) in order to maintain comparability with the skill-content and the share of the low-skilled in the US, represented by high-school drop-outs. ${ }^{41}$

The employment and the labor force participation rates are defined in the standard way: Employed individuals include the employed and the self-employed, as well as the unpaid family workers, and labor force participants are individuals who are

\footnotetext{
${ }^{41}$ Steedman and McIntosh (2001) do not have the US in their cross-country comparisons.
} 
either employed or unemployed (according to the ILO definition of unemployment). Earnings are measured by the real hourly wage. In France, the hourly wage was constructed using the reported monthly wages from the previous month divided by 4.33 times the reported usual hours of work. In the UK, the hourly wage was already present in the dataset, constructed by the data providers using the reported current weekly wages and usual hours of work. In the US, hourly wage was constructed from the annual wage from the previous year, using the reported weeks worked in the previous year multiplied by the usual weekly hours of work. The reported hours of work per week were first trimmed (separately by gender and year) at the 1st and 99th percentile to avoid the outliers and top coded values. The resulting hourly wages were trimmed at the 5th and 95th percentile (separately by year and within each skill-group) for the same reason. The consumption deflators for the period come from the official statistical sites of the three countries: Personal Consumption Expenditure Deflator from the Bureau of Economic Analysis for the US, IPC (Indice des prix à la consommation) from INSEE (French Statistical National Institute) for France, and CPI index (all items) from National Statistics in the UK. All three indices are normalized to have a base in 1995.

The value added shares of the individual industries used in the construction of the demand shifter come from the STAN Indicators database produced by OECD. There are 25 industry groups in the US, 24 in the UK, and 23 in France. The number of industries depends on the extent to which the national industry classifications in the individual level datasets correspond to the ISIC Rev.3 classification in the STAN database.

Marital status (including cohabitation, given the increasing popularity of this arrangement) is defined as follows: "married with spouse present" in the US, ${ }^{42}$, "married with spouse present OR cohabitate" in the UK and "cohabitate" (both married or not) in France. Following the available survey definitions, the presenceof-children variable is defined as the presence of pre-school (less than 6 year old in

\footnotetext{
${ }^{42}$ It is not possible to distinguish individuals that are not married but are living together the US dataset.
} 
the US and France, and less than 5 year old in the UK) children in the household.

\section{A.3 Construction of Group-Level Wages}

The wages of non-employed were first imputed using the standard two-equation model of Heckman, estimated jointly by maximum likelihood. The right-hand-side variables in the wage equation are age, age squared, dummy variables for the six (five in the UK) education categories, ethnicity, ${ }^{43}$ immigration status, and an indicator whether the individual is employed full-time. Marital/cohabitation status and the presence of pre-school age children in the household were used as the usual exclusion restrictions. The model is estimated separately by gender, country and year. The group specific wage is constructed as a median of wages of all the individuals in the group. Whenever the predicted wages of non-employed are below those of the employed within a group, this procedure is equivalent to an alternative approach of assigning zeros as the wages of the non-employed in a median regression context (see Olivetti and Petrongolo (2008)).

\footnotetext{
${ }^{43}$ This variable is not present in the French dataset and therefore is not used in the estimation
} for France. 


\section{A.4 Model Details}

\section{A.4.1 Correspondences between the structure and the reduced form}

The $J$ group-specific fixed effects and the $T$ year-specific fixed effects correspond to the underlying parameters as follows

$$
\begin{aligned}
\pi_{1 j}^{w} & =\omega_{j}-\frac{\rho}{\sigma+\varepsilon} \alpha_{j} \\
\pi_{1 j}^{e} & =\frac{\sigma \rho}{\sigma+\varepsilon} \alpha_{j}-\sigma \omega_{j} \\
\pi_{1 j}^{s} & =\left(1-\frac{\varepsilon \rho}{\sigma+\varepsilon}\right) \alpha_{j}+\varepsilon \omega_{j} \\
\pi_{0 t}^{w} & =\eta_{t}+\frac{\rho}{\sigma+\varepsilon}\left(\ln \left(y_{t}\right)+(\sigma-1) \lambda_{0 t}\right) \\
\pi_{0 t}^{e} & =\ln \left(y_{t}\right)-\sigma \eta_{t}+(\sigma-1)\left(1-\frac{\sigma \rho}{\sigma+\varepsilon}\right) \lambda_{0 t} \\
\pi_{0 t}^{s} & =\varepsilon \eta_{t}+\frac{\varepsilon \rho}{\sigma+\varepsilon}\left(\ln \left(y_{t}\right)+(\sigma-1) \lambda_{0 t}\right)
\end{aligned}
$$

The error terms in the estimated model map into the underlying error terms as follows

$$
\begin{aligned}
\xi_{j t}^{w} & =\frac{\rho}{\sigma+\varepsilon}\left(\nu_{j t}^{d}-\nu_{j t}^{s}\right)+\nu_{j t}^{w}+\frac{\rho(\sigma-1)}{\sigma+\varepsilon} \nu_{j t}^{c} \\
\xi_{j t}^{e} & =\frac{\sigma \rho}{\sigma+\varepsilon} \nu_{j t}^{s}-\sigma \nu_{j t}^{w}+\left(1-\frac{\sigma \rho}{\sigma+\varepsilon}\right) \nu_{j t}^{d}+(\sigma-1)\left[1-\frac{\sigma \rho}{\sigma+\varepsilon}\right] \nu_{j t}^{c} \\
\xi_{j t}^{s} & =\frac{\varepsilon \rho}{\sigma+\varepsilon} \nu_{j t}^{d}+\varepsilon \nu_{j t}^{w}+\left(1-\frac{\varepsilon \rho}{\sigma+\varepsilon}\right) \nu_{j t}^{s}+\frac{\varepsilon \rho(\sigma-1)}{\sigma+\varepsilon} \nu_{j t}^{c}
\end{aligned}
$$




\section{A.4.2 Identification}

The model is described by the following system of equations

$$
\begin{aligned}
\ln \left(l_{j t}^{d}\right) & =\ln \left(y_{t}\right)-\sigma \ln \left(w_{j t}\right)+(\sigma-1) \ln \left(c_{j t}\right)-\ln \left(p_{j t}\right)+\nu_{j t}^{d} \\
\ln \left(\begin{array}{c}
s \\
j t
\end{array}\right) & =\alpha_{j}+\varepsilon \ln \left(w_{j t}\right)+\beta^{g} m_{j t}+\gamma^{g} k_{j t}+\nu_{j t}^{s} \\
l_{j t}^{s}\left(w_{j t}^{*}\right) & \equiv l_{j t}^{d}\left(w_{j t}^{*}\right) \\
\ln \left(w_{j t}\right) & =\eta_{t}+\omega_{j}+\rho \ln \left(w_{j t}^{*}\right)+\nu_{j t}^{w} \\
u_{j t} & \equiv l_{j t}^{s}-l_{j t}^{d} \\
e_{j t} & \equiv l_{j t}^{d} \\
1 & \equiv e_{j t}+u_{j t}+n_{j t}
\end{aligned}
$$

This system simplifies to (omitting the time subscripts)

$$
\begin{aligned}
\ln \left(e_{j}\right) & =\ln (y)-\sigma \ln \left(w_{j}\right)+(\sigma-1) \ln \left(c_{j}\right)-\ln \left(p_{j}\right)+\nu_{j}^{d} \\
\ln \left(\begin{array}{l}
s \\
j
\end{array}\right) & =\alpha_{j}+\varepsilon \ln \left(w_{j}\right)+\beta^{g} m_{j}+\gamma^{g} k_{j}+\nu_{j}^{s} \\
\ln \left(w_{j}\right) & =\eta+\omega_{j}+\rho \frac{1}{\varepsilon+\sigma}\left[\ln (y)-\alpha_{j}-\beta^{g} m_{j}-\gamma^{g} k_{j}+(\sigma-1) \ln \left(c_{j}\right)-\ln \left(p_{j}\right)+\nu_{j}^{d}-\nu_{j}^{s}\right]+\nu_{j}^{w} \\
1 & \equiv{ }_{j}^{s}+n_{j}
\end{aligned}
$$

The way the model is set up and the substantial number of parameters (including the group and the year effects as described in the Section A.4.1) makes the traditional proof of identification through the rank and order conditions rather complicated. Therefore in what follows, we use an easier method of step by step description of how the key structural parameters could be recovered from particular reduced-form estimates.

The key parameters can be inferred from the reduced-form coefficients given by $\pi$-s, for example, as follows. The ratio of the coefficient of the proportion of the group in the population from the labor force participation equation to the same coefficient in the wage equation gives the wage elasticity of labor supply. ${ }^{44}$

\footnotetext{
44 The same is true for the corresponding ratio of the two coefficients of the demand shifter.
} 
The ratio of the coefficient of the presence of pre-school children for women in the employment equation to the one in the wage equation can be used to calculate $\sigma$. The coefficient of the group's proportion within the population in the wage equation and the previous estimates of $\varepsilon$ and $\sigma$ enable construction of $\rho$. The four parameters associated with the exogenous labor supply shifters can be recovered from the wage equation alone: They are equal to the ratio of the respective genderspecific coefficients of the variables describing marital status and children, and the coefficient of the proportion of the group in the population. The coefficient of the proxy variable for the relative efficiency $(\lambda)$ is minus the ratio of the demand shifter and the population fraction coefficients from the wage equation, divided by $(\sigma-1)$. We can plug in the expression for $\sigma$ as derived before. All the formulas are summarized below.

$$
\begin{aligned}
\varepsilon & =\frac{\pi_{p}^{s}}{\pi_{p}^{w}} ; \quad \sigma=-\frac{\pi_{k}^{f e}}{\pi_{k}^{f w}} \\
\rho & =-\pi_{p}^{w}(\sigma+\varepsilon)=-\pi_{p}^{w}\left(-\frac{\pi_{k}^{f e}}{\pi_{k}^{f w}}+\frac{\pi_{p}^{s}}{\pi_{p}^{w}}\right) \\
\beta^{f} & =\frac{\pi_{m}^{f w}}{\pi_{p}^{w}} ; \quad \beta^{m}=\frac{\pi_{m}^{m w}}{\pi_{p}^{w}} \\
\gamma^{f} & =\frac{\pi_{k}^{f w}}{\pi_{p}^{w}} ; \quad \gamma^{m}=\frac{\pi_{k}^{m w}}{\pi_{p}^{w}} \\
\lambda_{1} & =-\frac{\pi_{\tilde{c}}^{w}}{\pi_{p}^{w}}\left(\frac{1}{\sigma-1}\right)=\left(\frac{\pi_{\tilde{c}}^{w}}{\pi_{p}^{w}}\right)\left(\frac{\pi_{k}^{f w}}{\pi_{k}^{f w}+\pi_{k}^{f e}}\right)
\end{aligned}
$$

\section{A.4.3 Restriction Imposed on $\lambda$}

The non-linear structure of the model with linear relationships between different sets of the reduced-form coefficients both within and across equations requires - in order to achieve convergence of the model - one of the parameters to be constrained. Although all parameters are theoretically identified, as shown in section A.4.2, the way in which $\lambda$ and $\sigma$ appear in the demand shifter coefficient together for all three equations make the estimation of their values unstable. For this reason, we choose $\lambda$, the parameter of the relationship between the unobserved relative productivity 
coefficients and the demand shifter (a coefficient which is of the least interest to the present analysis) to be constrained to one in the estimation. This constraint has a straightforward interpretation and corresponds to the following assumption: if $\lambda=1$, the relationship between the logarithm of unobserved productivity and the logarithm of the share in the value added in the previous year becomes $\ln \left(c_{j t}\right)=$ $\lambda_{0 t}+\ln \left(\tilde{c}_{j t}\right)+\nu_{j t}^{c}$. This restricts the relationship between the two variables to being linear, although changing in time, as captured by $\exp \left(\lambda_{0 t}\right)$. The one percentage change in the group $j$ 's relative efficiency is therefore directly measured by one percentage change in the group $j$ 's share in the value added produced in the economy in the previous year. 


\section{Working Paper Series}

ISSN 1211-3298

Registration No. (Ministry of Culture): E 19443

Individual researchers, as well as the on-line and printed versions of the CERGE-EI Working Papers (including their dissemination) were supported from institutional support RVO 67985998 from Economics Institute of the ASCR, v. v. i.

Specific research support and/or other grants the researchers/publications benefited from are acknowledged at the beginning of the Paper.

(c) Alena Bičáková, 2014

All rights reserved. No part of this publication may be reproduced, stored in a retrieval system or transmitted in any form or by any means, electronic, mechanical or photocopying, recording, or otherwise without the prior permission of the publisher.

Published by

Charles University in Prague, Center for Economic Research and Graduate Education (CERGE) and

Economics Institute of the ASCR, v. v. i. (EI)

CERGE-El, Politických vězňů 7, 11121 Prague 1, tel.: +420 224005 153, Czech Republic.

Printed by CERGE-EI, Prague

Subscription: CERGE-EI homepage: http://www.cerge-ei.cz

Phone: + 420224005153

Email: office@cerge-ei.cz

Web: http://www.cerge-ei.cz

Editor: Marek Kapička

The paper is available online at http://www.cerge-ei.cz/publications/working_papers/.

ISBN 978-80-7343-306-2 (Univerzita Karlova. Centrum pro ekonomický výzkum a doktorské studium)

ISBN 978-80-7344-299-6 (Akademie věd České republiky. Národohospodářský ústav) 
CERGE-EI

P.O.BOX 882

Politických vězňů 7

11121 Praha 1

Czech Republic http://www.cerge-ei.cz 